\title{
Microsatellites in the genus Xiphophorus, developed in Xiphophorus montezumae
}

\author{
J. SECKINGER, H. BRINKMANN and A. MEYER \\ Department of Biology, University of Konstanz, Universitätsstrasse 10, LS Evolutionsbiologie, Fach M617, 78457 Konstanz, Germany
}

\begin{abstract}
Species of the genus Xiphophorus (swordtails and platies) are of great interest for the study of evolution of sexually selected traits like the sword, which is an elongation of ventral fin rays of the male caudal fin, that has evolved in several species within this genus. The detection of $\mathbf{1 0}$ microsatellites within the genus Xiphophorus will enable studies about the correlation of this trait with sexual reproductive success of males possessing swords of different lengths. These microsatellites will also be useful in determining population structure and enable paternity analysis in these species, where sperm storage is widespread.
\end{abstract}

Keywords: microsatellites, multiple paternity, Poeciliidae, sexually selected traits, sword, Xiphophorus

Received 26 April 2001; revision received 20 June 2001; accepted 12 July 2001

The 22 species of platies and swordtails belong to the genus Xiphophorus. This genus is one of the 22 genera composing the family Poeciliidae, a widespread and diverse group of small-sized fishes that are endemic to the New World. Poeciliids have internal fertilization and bear live young (except for one species, which is a facultative livebearer), hence their common name, the livebearers. Xiphophorids are model organisms in several biological subdisciplines, such as research on sexual selection, particularly mating preference (Basolo 1990, 1991, 1995), and cancer research (Schartl et al. 1999). Phylogenetic studies have largely resolved evolutionary relationships among species within Xiphophorus (Meyer et al. 1994; Meyer 1997), but no genetic work at the population level has been conducted.

In this note we present 10 microsatellite loci that will aid further genetic studies of these fish and their relatives. Up to now, there is no information concerning the population structure or mating systems in Xiphophorus. Female choice experiments demonstrate that females spend more time in courtship behaviour with males possessing longer swords (Basolo 1995). Moreover, platy females seem to prefer heterospecific males with swords over their conspecific swordless males (Basolo 1990). Paternity analysis using microsatellites could resolve remaining questions about the fitness of swords in males. Microsatellites can also provide

Correspondence: Axel Meyer. Fax: 0049753188 3018; E-mail: Axel.Meyer@uni-konstanz.de information about population structure, variability in natural populations and even about mating systems. Microsatellite studies offer many opportunities for future behavioural and ecological studies of species of the genus Xiphophorus.

Genomic DNA from Xiphophorus montezumae was used to screen for microsatellites. DNA from a single fish was extracted, following a general phenol-chloroform extraction protocol and stored in $\mathrm{ddH}_{2} \mathrm{O}$. DNA was digested with the restriction enzyme Sau3AI and fragments of a size of 300-1000 bp were ligated into the bluescript vector pBS (Stratagene), and the vectors transfected into electrocompetent bacteria. Microsatellites were screened with dioxygenin-labeled di-/tri- and tetranucleotide-repeats. Plasmids from positive clones were extracted with a plasmid extraction kit (Quiagen), and the inserts were sequenced with universal primers M13F and M13R.

The primers for the amplification of Xiphophorus DNA were designed with the program oligo $4.0-\mathrm{s}$, and placed approximately 100-150 bp away from the microsatellite in an effort to standardize amplification products to a range between 200 and 400 bp. Amplification was carried out in a GeneAmp PCR System 9700 Thermocycler (ABI). The polymerase chain reaction (PCR) conditions were $3 \mathrm{~min}$ denaturing at $94^{\circ} \mathrm{C}$, then 35 cycles of $35 \mathrm{~s}$ denaturing $\left(94^{\circ} \mathrm{C}\right), 35 \mathrm{~s}$ primer annealing (between 46 and $52^{\circ} \mathrm{C}$ (Table 1), and $75 \mathrm{~s}$ for elongation at $72{ }^{\circ} \mathrm{C}$, and a final elongation of $7 \mathrm{~min}$ at $72{ }^{\circ} \mathrm{C}$. Two $\mu \mathrm{L}$ of the PCR product were precipitated with $95 \% \mathrm{EtOH}$, washed with $70 \% \mathrm{EtOH}$ 
Table 1 Ten microsatellites in overview

\begin{tabular}{|c|c|c|c|c|c|c|c|c|}
\hline $\begin{array}{l}\text { Locus } \\
\text { name }\end{array}$ & Primer sequence $\left(5^{\prime}-3^{\prime}\right)$ & $\begin{array}{l}T_{\mathrm{a}} \\
\left({ }^{\circ} \mathrm{C}\right)\end{array}$ & $\begin{array}{l}\text { Repeat of } \\
\text { cloned } \\
\text { allele }\end{array}$ & $\begin{array}{l}\text { Size in } \\
\text { bp of } \\
\text { cloned allele }\end{array}$ & $\begin{array}{l}\text { Length } \\
\text { variation of } \\
\text { alleles in bp }\end{array}$ & $\begin{array}{l}\text { No. } \\
\text { of alleles }\end{array}$ & $H_{\mathrm{O}}$ & $H_{\mathrm{E}}$ \\
\hline KonD3 & $\begin{array}{l}\text { F: AGTAAGTAATTGACAAGGAG } \\
\text { R: TGAATTTGAATACAAGTATG }\end{array}$ & 46 & $(\mathrm{GT})_{11}$ & 423 & 423 & $\mathrm{x}$ & $\mathrm{x}$ & $\mathrm{x}$ \\
\hline KonD6 & $\begin{array}{l}\text { F: CTTTAATACCCAATCAGTGG } \\
\text { R: CAACTGGAAGAGGAGTTGTC }\end{array}$ & 53 & $(\mathrm{CA})_{7}$ & 205 & 205-209 & 3 & 0.133 & 0.131 \\
\hline KonD8 & $\begin{array}{l}\text { F: CCAAGGATATTGCTGACTCC } \\
\text { R: TTCACTGAGCTTAAAGGCAG }\end{array}$ & 51 & $(\mathrm{CA})_{7}$ & 360 & $360-362$ & 2 & 0.267 & 0.248 \\
\hline KonD10 & $\begin{array}{l}\text { F: CAGGACTTAGAATTAACAGG } \\
\text { R: AGAACCAGTTGGACTGACAG }\end{array}$ & 52 & $(\mathrm{CA})_{13}$ & 283 & 283 & $\mathrm{x}$ & $\mathrm{x}$ & $x$ \\
\hline KonD15 & $\begin{array}{l}\text { F: CATCCAGCCTGCTTAGTGAG } \\
\text { R: TGTTCGTCATTAATTTGCAG }\end{array}$ & 52 & $(\mathrm{CA})_{17}$ & 275 & $273-275$ & 6 & 0.600 & 0.777 \\
\hline KonD21 & $\begin{array}{l}\text { F: TCATCTGGAGCAGGCACATG } \\
\text { R: GCGTTTGGTTTCCTACTGAC }\end{array}$ & 57 & $(\mathrm{CA})_{15}$ & 273 & $265-285$ & 10 & 1.000 & 0.784 \\
\hline KonD26 & $\begin{array}{l}\text { F: CTTCTCCAACCAAAGAACTG } \\
\text { R: TTGCAGACTGCTTTGTTCTG }\end{array}$ & 54 & $(\mathrm{GT})_{13}$ & 343 & $341-345$ & 3 & 0.533 & 0.481 \\
\hline KonD29 & $\begin{array}{l}\text { F: CAGAACGATGAAACAGAATC } \\
\text { R: TGACCATGTCTACAGAGTGG }\end{array}$ & 52 & $(\mathrm{GT})_{12}$ & 290 & $290-296$ & 4 & 0.600 & 0.476 \\
\hline KonT30 & $\begin{array}{l}\text { F: CCCAGTTTTATTATTATCAT } \\
\text { R: GGAAGAGATTTTATTATTAT }\end{array}$ & 48 & $(\mathrm{TAA})_{10}$ & 144 & $135-177$ & 9 & 0.867 & 0.667 \\
\hline KonT38 & $\begin{array}{l}\text { F: CGACGTGTAGAAACTGAGTA } \\
\text { R: CTCTATTCCTGGTTTGACAT }\end{array}$ & 49 & $(\mathrm{ATT})_{6}$ & 169 & $160-181$ & 8 & 0.800 & 0.802 \\
\hline
\end{tabular}

KonD, dinucleotide-repeats; KonT, trinucleotide-repeats. $T_{\mathrm{a}^{\prime}}$ annealing temperature; $H_{\mathrm{O}}$, observed heterozygosity; $H_{\mathrm{E}^{\prime}}$ expected heterozygosity; bp, basepairs; $x$, no PCR amplification for X. multilineatus but for other species of Xiphophorus. GenBank accession numbers AF368425-AF368434.

\begin{tabular}{lllll}
\hline Locus name & X. multilineatus & X.cortezi & X. birchmanni & X. maculatus \\
\hline KonD3 & variable & $?$ & $?$ & $?$ \\
KonD6 & variable & not variable & $?$ & $?$ \\
KonD8 & variable & variable & variable & variable \\
KonD10 & not variable & not variable & not variable & variable \\
KonD15 & variable & $?$ & $?$ & variable \\
KonD21 & variable & variable & variable & variable \\
KonD26 & variable & not variable & $?$ & not variable \\
KonD29 & variable & not variable & $?$ & not variable \\
KonT30 & variable & variable & variable & variable \\
KonT38 & variable & variable & variable & variable \\
\hline
\end{tabular}

Table 2 Variability of the microsatellite loci in different species of Xiphophorus

?, no amplification-product with PCR; not variable, monomorphic locus for that species; variable, two or more alleles at this locus.

and dried in a speed vacuum for $6 \mathrm{~min}$. The DNA-pellet was redisolved in $4 \mu \mathrm{L}$ of a mixture of formamide-blue dextran (5:1) and $0.25 \mu \mathrm{L}$ of a length standard, GeneScan-500 [ROX] Size Standard (PE Applied Biosystems). The variability of the detected microsatellites was tested on an acrylamide-gel and analysed on an ABI Prism 377 DNA Sequencer. An amount of $1.8 \mu \mathrm{L}$ of the mixture was loaded in each lane. Data were analysed with the GENESCAN software (Perkin Elmer).

Variability was tested in several species of the genus Xiphophorus (Table 2). All microsatellite loci were also sequenced in at least two individuals of each species to test if the amplification products were the homologous microsatellite loci, and if the variability is restricted to the microsatellite repeats and not to the flanking regions. Sequencing reactions followed the manufacturer's protocol (ABI) and the products were loaded on a polyacrylamide gel on the ABI Prism 377 DNA Sequencer. We analysed the sequence data with Sequencing Analysis and Sequence Navigator (ABI Biosystems).

In total, we identified 10 variable microsatellites in $X$. multilineatus, X. cortezi, X. birchmanni and X. maculatus, but not all were variable in all species (Table 2). Most of the tests for variability were made in X. multilineatus, where 15 different samples from three different locations were tested. 
Eight out of 10 tested loci were variable in this species, with up to 10 different alleles per locus (Table 1).

The heterogeneity of the microsatellites varies among species. Some microsatellites that are monomorphic for $X$. multilineatus are variable in other species of Xiphophorus (Table 2). Because we sampled data for members of some representative species of Xiphophorus (see phylogenetic tree in Meyer et al. 1994), these primers should work in the majority of Xiphophorus species. These microsatellites can therefore become an important tool for future behavioural and ecological studies within the genus Xiphophorus.

\section{Acknowledgements}

The work was partially supported by grants of the DFG (Deutsche Forschungsgemeinschaft), Vern Parish Fund and the Landesgraduierten-Foerderungsstipendium-scholarship to JS.

\section{References}

Basolo AL (1990) Female preference predates the evolution of the sword in swordtail fish. Science, 250, 808-810.

Basolo AL (1991) Male swords and female preferences. Science, 253, 1426-1427.

Basolo AL (1995) A further examination of a pre-existing bias favouring a sword in the genus Xiphophorus. Journal of Animal Behaviour, 50, 365-375.

Meyer A (1997) The evolution of sexually selected traits in male swordtail fishes (Xiphophorus: Poecilidae). Heredity, 79, 329337.

Meyer A, Morrissey JM, Schartl M (1994) Recurrent origin of a sexually trait in Xiphophorus fishes inferred from a molecular phylogeny. Nature, 168, 539-542.

Schartl M, Hornung U, Gutbrod H, Volff JN, Wittbrodt J (1999) Melanoma loss-of-function mutants in Xiphophorus caused by Xmrk-oncogene deletion and gene disruption by a transposable element. Genetics, 153, 1385-1394. 